\title{
Pengaruh Corporate Social Responsibility dan Mekanisme Corporate Governance Terhadap Nilai Perusahaan
}

\author{
Rika Astrinika; H. Sri Sulistyanto \\ email: hsrisulistyanto@gmail.com \\ Program Studi Akuntansi, Fakultas Ekonomi dan Bisnis \\ Universitas Katolik Soegijapranata
}

\begin{abstract}
This study examines the influence of CSR and the mechanism of GCG on firm value. The main reasons are, first, disclosure of social responsibility is very important for the company's reputation. Second, CSR is no longer voluntary. Third, CSR disclosure can be linked to corporate governance. By using a sample of manufacturing companies listed on the Stock Exchange in 2011-2015, this study provides results that (1) disclosure has a positive and significant influence on firm value, (2) managerial ownership has a positive and insignificant influence on the value of the company, (3) institutional ownership has a negative and insignificant effect on the value of the company, (4) an independent board of directors has a positive and significant influence on the value of the company, and (5) the audit committee has a positive influence and significant influence on the value of the company
\end{abstract}

Keywords: CSR, managerial ownership, institutional ownership, audit committee, company value.

\section{PENDAHULUAN}

Penelitian Susilawati (2009), Permanasari (2010), Rustiarini (2010), Saputra (2010) menyatakan bahwa pengungkapan corporate social responsibility (CSR) berpengaruh pada nilai perusahaan. Sementara itu, hubungan CSR dengan nilai perusahaan juga diteliti oleh Nurlela dan Islahudin (2008) yang menunjukan hasil bahwa CSR tidak berpengaruh signifikan terhadap nilai perusahaan. Penelititan Dahlia dan Siregar (2008), Suhartati dkk. (2011), Susanto dan Subekti (2012), serta Wardoyo dan Veronica (2013) juga menunjukan bahwa CSR tidak berpengaruh pada kinerja pasar perusahaan. Penelitian Rachmawati dan Triatmoko (2007), Saputra (2010), Susanti dkk. (2010), Sofyaningsih dan Hardiningsih (2011), serta Susanto dan Subekti (2012), menunjukkan bahwa kepemilikan manajerial berpengaruh positif terhadap nilai perusahaan. Siallagan 
dan Machfoedz (2006), Pujiati dan Widanar (2006) dan Kawatu (2009) menunjukan bahwa kepemilikan manajerial berpengaruh negatif terhadap nilai perusahaan, sedangkan Animah dan Ramadhani (2008), Murwaningsari (2008), serta Permanasari (2010) tidak menemukan pengaruh kepemilikan manajerial terhadap nilai perusahaan. Hasil penelitian yang telah dilakukan olehRachmawati dan Triatmoko (2007),Murwaningsari (2009), Susanti dkk. (2010), Anggraini (2012), serta Sukirni (2012).menemukan bahwa kepemilikan institusional mempunyai pengaruh yang positif terhadap nilai perusahaan.Temuan tersebut menunjukkan bahwa kepemilikan institusional menjadi mekanisme yang handal, sehingga mampu memotivasi manajer dalam meningkatkan kinerjanya. Sedangkan Pujiati dan Widanar (2006), Murwaningsari (2008), Permanasari (2010), Saputra (2010), Sofyaningsih dan Hardiningsih (2011), Susanto dan Subekti (2012) menemukan bahwa kepemilikan institusional tidak berpengaruh signifikan terhadap nilai perusahaan.

Dewan komisaris sebagai puncak dari sistem pengelolaan internal perusahaan, memiliki peranan terhadap aktivitas pengawasan. Fungsi monitoring yang dilakukan oleh dewan komisaris dipengaruhi oleh jumlah atau ukuran dewan komisaris (Siallagan dan Machfoedz, 2006). Penelitian Siallagan dan Machfoedz (2006), Animah dan Ramadhani (2008), Murwaningsari (2008), Kawatu (2009), Febrina (2010),Suhartati dkk. (2011), serta Susanto dan Subekti (2012) menemukan bahwa dewan komisaris independen secara positif berpengaruh terhadap nilai perusahaan. Sedangkan Rachmawati dan Triatmoko (2007), Purwanto (2009), Susanti dkk. (2010), Sofyaningsih dan Hardiningsih (2011), serta Wardoyo dan Veronica (2013) menemukan bahwa dewan komisaris independen tidak berpengaruh terhadap nilai perusahaan.

Komite audit mempunyai peran yang sangat penting dan strategis dalam hal memelihara kredibilitas proses penyusunan laporan keuangan seperti halnya menjaga terciptanya sistem pengawasan perusahaan yang memadai, serta dilaksanakannya good corporate governance. Dengan berjalannya fungsi komite audit secara efektif, maka kontrol terhadap perusahaan akan lebih baik, sehingga 
konflik keagenan yang terjadi akibat keinginan manajemen untuk meningkatkan kesejahteraannya sendiri dapat diminimalisasi (Rachmawati dan Triatmoko, 2007). Siallagan dan Machfoedz (2006), Murwaningsari (2008), serta Kawatu (2009) menemukan bahwa komite audit secara positif dan signifikan mempengaruhi nilai perusahaan, sedangkan penelitian Suhartati dkk. (2011), Susanto dan subekti (2012), serta Wardoyo dan Veronica (2013) tidak menemukan pengaruh komite audit terhadap nilai perusahaan. Berdasarkan fenomena dan research gap akan ketidakkonsistenan hasil penelitian terdahulu, maka penelitian ini dilakukan untuk menguji:

1. Apakah corporate social responsibility berpengaruh positif terhadap nilai perusahaan?

2. Apakah kepemilikan manajerialberpengaruh positif terhadap nilai perusahaan?

3. Apakah kepemilikan institusional berpengaruh positif terhadap nilai perusahaan?

4. Apakah dewan komisaris independen berpengaruh positif terhadap nilai perusahaan?

5. Apakah komite audit berpengaruh positif terhadap nilai perusahaan?

\section{TINJAUAN LITERATUR DAN PENGEMBANGAN HIPOTESIS}

\section{Pengaruh Corporate Social ResponsibilityTerhadap Nilai Perusahaan}

Hasil penelitian Harjoto dan Jo (2007) dalam Rustiarini (2010) menemukan bahwa pengungkapan CSR berpengaruh positif terhadap nilai perusahaan. Hal ini didukung juga oleh penelitian yang dilakukan oleh penelitian Susilawati (2009).Hasil penelitian yang dilakukan oleh Permanasari (2010) memberikan hasil yang sama. Hasil penelitian Rustiarini (2010) juga menemukan CSR berpengaruh positif terhadap nilai perusahaan. Hasil penelitian yang dilakukan oleh Saputra (2010) memberikan hasil yang sama. Dengan demikian hipotesis pertama dalam penelitian ini adalahsebagai berikut.

$H_{1}$ : Corporate Social Responsibility berpengaruh positif dan signifikan terhadap nilai perusahaan 


\section{Pengaruh Kepemilikan ManajerialTerhadap Nilai Perusahaan}

Nurlela dan Islahuddin (2008) menyatakan bahwa kepemilikan manajemen adalah persentase kepemilikan saham yang dimiliki oleh direksi, manajer dan dewan komisaris. Dengan adanya kepemilikan manajemen dalam sebuah perusahaan akan menimbulkan dugaan bahwa nilai perusahaan meningkat sebagai akibat kepemilikan manajemen yang meningkat. Rachmawati dan Triatmoko (2007) menyatakan bahwa kepemilikan manajerial berpengaruh terhadap nilai perusahaan. Saputra (2010) menyatakan bahwa kepemilikan manajerial berpengaruh positif terhadap nilai perusahaan. Susanti, dkk (2010) menyatakan bahwa kepemilikan manajerial berpengaruh terhadap nilai perusahaan. Demikian juga dengan penelitian Sofyaningsih dan Hardiningsih (2011) serta Susanto dan Subekti (2012). Dengan demikian hipotesis kedua dalam penelitian ini adalahsebagai berikut.

$\mathrm{H}_{2}$ : Kepemilikan manajerial berpengaruh positif dan signifikan terhadap nilai perusahaan

\section{Pengaruh Kepemilikan InstitusionalTerhadap Nilai Perusahaan}

Penelitian yang dilakukan oleh Rachmawati dan Triatmoko (2007) sampelnya adalah menyimpulkan bahwa kepemilikan institusional berpengaruh positif terhadap nilai perusahaan.Hasil penelitian ini didukung oleh Murwaningsari (2009). Susanti, dkk (2010) menyatakan bahwa kepemilikan institusional berpengaruh terhadap nilai perusahaan. Penelitian yang dilakukan oleh Sukirni (2012) juga menyatakan bahwa kepemilikan institusional berpengaruh terhadap nilai perusahaan. Penelitian lainnya dilakukan oleh Anggraini (2012) menyatakan bahwa kepemilikan institusional mempunyai hubungan yang sangat kuat dan berpengaruh signifikan terhadap nilai perusahaan. Dengan demikian hipotesis ketiga dalam penelitian ini adalah sebagai berikut.

$H_{3}:$ Kepemilikan instutisional berpengaruh positif dan signifikan terhadap nilai perusahaan 


\section{Pengaruh Dewan Komisaris IndependenTerhadap Nilai Perusahaan}

Penelitian yang dilakukan oleh Animah dan Ramadhani (2008) menyimpulkan bahwa dewan komisaris independen berpengaruh positif terhadap nilai perusahaan. Hasil penelitian ini didukung oleh Murwaningsari (2008) yang menyatakan hal yang serupa.Penelitian yang dilakukan oleh Kawatu (2009) menyimpulkan bahwa dewan komisaris independen berpengaruh terhadap nilai perusahaan. Demikian juga dengan penelitian yang dilakukan oleh Febrina (2010), Suhartati dkk. (2011), serta Susanto dan Subekti (2012). Dengan demikian hipotesis keempat dalam penelitian ini adalah sebagai berikut.

H4: Dewan komisaris independen berpengaruh positif dan signifikan terhadap nilai perusahaan

\section{Pengaruh Komite Audit Terhadap Nilai Perusahaan}

Siallagan dan Machfoedz (2006) menyatakan bahwa komite audit berpengaruh positif terhadap nilai perusahaan. Hal ini didukung oleh Murwaningsari (2008) dan Kawatu (2009) yang menyimpulkan bahwa komite audit berpengaruh positif terhadap nilai perusahaan. Semakin banyak jumlah komite audit menunjukkan bahwa semakin banyak pertimbangan dan monitoring dari auditor terhadap kinerja perusahaan, sehingga akan membuat nilai perusahaannya menjadi semakin meningkat. Dengan demikian hipotesis kelima dalam penelitian ini adalahsebagai berikut.

$H_{5}$ : Komite audit berpengaruh positif dan signifikan terhadap nilai perusahaan 


\section{METODE PENELITIAN}

Populasi penelitian ini adalah semua perusahaan public yang listing di Bursa Efek Indonesia (BEI) tahun 2011-2015.

Tabel 1 Sampel Penelitian

\begin{tabular}{lcccccc}
\hline Keterangan & $\mathbf{2 0 1 1}$ & $\mathbf{2 0 1 2}$ & $\mathbf{2 0 1 3}$ & $\mathbf{2 0 1 4}$ & $\mathbf{2 0 1 5}$ & Total \\
\hline $\begin{array}{l}\text { Perusahaan manufaktur terdaftar di } \\
\text { BEI }\end{array}$ & 148 & 146 & 152 & 155 & 155 & 756 \\
\hline $\begin{array}{l}\text { Laporan tahunan tidak dapat } \\
\text { diakses }\end{array}$ & $(15)$ & $(7)$ & $(3)$ & $(1)$ & $(9)$ & $(35)$ \\
\hline $\begin{array}{l}\text { Tidak memiliki data kepemilikan } \\
\text { manajerial }\end{array}$ & $(78)$ & $(80)$ & $(84)$ & $(78)$ & $(79)$ & $(399)$ \\
\hline $\begin{array}{l}\text { Tidak memiliki data kepemilikan } \\
\text { institusional }\end{array}$ & $(4)$ & $(5)$ & $(4)$ & $(6)$ & $(6)$ & $(25)$ \\
\hline Menggunakan mata uang dollar & $(2)$ & $(9)$ & $(9)$ & $(17)$ & $(14)$ & $(51)$ \\
\hline Data outlier & $(24)$ & $(22)$ & $(22)$ & $(24)$ & $(17)$ & $(109)$ \\
\hline Total & $\mathbf{2 5}$ & $\mathbf{2 3}$ & $\mathbf{3 0}$ & $\mathbf{2 9}$ & $\mathbf{3 0}$ & $\mathbf{1 3 7}$ \\
\hline
\end{tabular}

Sumber: Data sekunder diolah, 2017.

\section{HASIL DAN PEMBAHASAN}

Penelitian ini diuji dengan menggunakan regresi dengan persamaan sebagai berikut:

$$
\begin{array}{ll}
\mathrm{PBV}=\beta_{0} & +\beta_{1} \mathrm{CSRI}+\beta_{2} \mathrm{KM}+\beta_{3} \mathrm{KI}+\beta_{4} \mathrm{DKI}+\beta_{5} \mathrm{KA}+\varepsilon \\
\mathrm{PBV} & =\text { Nilai Perusahaan } \\
\mathrm{CSRI} & =\text { Corporate Social Responsibility } \\
\mathrm{KM} & =\text { Kepemilikan Manajerial } \\
\mathrm{KI} & =\text { Kepemilikan Institusional } \\
\mathrm{DKI} & =\text { Dewan Komisaris Independen } \\
\mathrm{KA} & =\text { Komite Audit } \\
\beta_{0} & =\text { Konstanta } \\
\beta_{1} \beta_{5} & =\text { Koefisien Regresi } \\
\varepsilon_{\mathrm{it}} & =\text { Error Term }
\end{array}
$$


Tabel 2 Statistik Deskriptif

\begin{tabular}{lrrrrr}
\hline & N & Minimum & Maximum & \multicolumn{1}{c}{ Mean } & Std. Deviation \\
\hline \hline PBV & 137 &, 102 & 1,434 &, 66946 &, 278559 \\
\hline CSRI & 137 &, 050 &, 640 &, 26248 &, 094338 \\
\hline KM & 137 &, 000100000 &, 282800000 &, 04831229401 &, 069331825965 \\
\hline KI & 137 &, 251 &, 985 &, 67948 &, 183131 \\
\hline DKI & 137 &, 200 &, 500 &, 36580 &, 071681 \\
\hline KA & 137 & 2,000 & 5,000 & 2,96350 &, 330079 \\
\hline $\begin{array}{l}\text { Valid N } \\
\text { (listwise) }\end{array}$ & 137 & & & & \\
\hline
\end{tabular}

Sumber: Data primer diolah, 2017.

Berdasarkan tabel di atas tampak pasar menghargai nilai buku saham perusahaan rata-rata sebesar 0,66946 kali. Jumlah pengungkapan item CSR yang dilakukan perusahaan adalah $26,24 \%$ dari total 78 item pengungkapan. Sementara rata-rata persentase jumlah saham yang dimiliki manajer dari total saham beredar perusahaan sampel sebanyak $4,83 \%$. Rata-rata persentase jumlah saham yang dimiliki institusi atau investor institusional dari total saham beredar perusahaan sampel sebanyak 67,94\%. Untuk persentase dewan komisaris independen dari perusahaan sampel sebanyak 36,58\%. Sedangkan dari jumlah komite audit perusahaan sampel telah sesuai aturan bahwa komite audit paling kurang terdiri dari 3 orang anggota.

\section{Tabel 3}

Pengaruh CSR, Kepemilikan Manajerial, Kepemilikan Institusional, Dewan Komisaris Independen Dan Komite Audit Terhadap Nilai Perusahaan

\begin{tabular}{|c|c|c|c|c|c|c|}
\hline & \multirow{2}{*}{ Model } & \multicolumn{2}{|c|}{$\begin{array}{c}\text { Unstandardized } \\
\text { Coefficients }\end{array}$} & \multirow{2}{*}{$\begin{array}{c}\text { Standardized } \\
\text { Coefficients }\end{array}$} & \multirow[t]{2}{*}{$\mathrm{t}$} & \multirow{2}{*}{ Sig. } \\
\hline & & $\mathrm{B}$ & Std. Error & & & \\
\hline \multirow{4}{*}{1} & (Constant) & 1,059 & 0,266 & & 3,985 & 0,000 \\
\hline & CSRI & 0,623 & 0,252 & 0,211 & 2,476 & 0,015 \\
\hline & $\mathrm{KM}$ & 0,378 & 0,356 & 0,094 & 1,063 & 0,290 \\
\hline & $\mathrm{KI}$ & $-0,047$ & 0,141 & $-0,031$ & $-0,335$ & 0,738 \\
\hline
\end{tabular}




\begin{tabular}{cccccc}
\hline DKI & 1,022 & 0,329 & 0,263 & 3,108 & 0,002 \\
\hline KA & 0,056 & 0,071 & 0,066 & 1,785 & 0,043 \\
\hline
\end{tabular}

a. Dependent Variable: PBV

F test: 3,610

Sig. F: $0,004^{\text {a }}$

R square: 0,121

Sumber: Data primer diolah, 2017.

Dari tabel di atas diketahui bahwa nilai beta dari CSRI adalah 0,211 dengan nilai t 2,476 dan sig 0,015. Dengan demikian dapat disimpulkan bahwa pengungkapan CSR berpengaruh positif dan signifikan terhadap nilai perusahaan dengan level signifikansi 5\%. Semakin tinggi CSRI maka akan semakin meningkatkan nilai perusahaan. Hasil penelitian ini sesuai dengan penelitian Harjoto dan Jo (2007), Susilawati (2009), Permanasari (2010), Rustiarini (2010), serta Saputra (2010). Nilai beta dari KM adalah 0,094 dengan nilai t1,063 dan sig 0,290. Dengan demikian dapat disimpulkan bahwa kepemilikan manajerial tidak berpengaruh signifikan terhadap nilai perusahaan. Kepemilikan manajerial adalah kepemilikan saham perusahaan yang dimiliki oleh manajer perusahaan itu sendiri. Mekanisme kepemilikan manajerial disini dapat dikatakan lemah karena tidak dapat berperan dalam upaya membatasi perilaku oportunistik manajer. Hal ini mungkin disebabkan oleh banyaknya perusahaan manufaktur yang listing di BEI belum memiliki kepemilikan manajerial. Hasil penelitian ini sejalan dengan penelitianyang dilakukan olehAnimah dan Ramadhani (2008), Murwaningsari (2008), serta Permanasari (2010).

Nilai beta dari KI adalah-0,031dengan nilai t-0,335dan sig 0,738. Dengan demikian dapat disimpulkan bahwa kepemilikan institusional tidak berpengaruh signifikan terhadap nilai perusahaan. Terdapatnya beberapa investor institusi dalam kepemilikan institusional menyebabkan pengendalian perusahaan tidak dapat dikoordinasikan sehingga investor institusi cenderung menjadi tidak maksimal dalam menekankan fungsi pengawasannya. Lebih dari satunya institusi yang memiliki satu perusahaan membuat kepemilikan menjadi tidak mayoritas 
sehingga fungsi monitoring menjadi kurang maksimal. Hal ini yang menyebabkan kepemilikan institusionalcenderung menjadi tidak berpengaruh terhadap aktivitas nilai perusahaan.Hasil penelitian ini sejalan dengan penelitian dari Pujiati dan widanar (2006), Murwaningsari (2008), Permanasari (2010), Saputra (2010), Sofyaningsih dan Hardiningsih (2011), Susanto dan subekti (2012).

Nilai beta dari DKI adalah 0,263 dengan nilai t 3,108 dan sig 0,002. Dengan demikian dapat disimpulkan bahwa dewan komisaris independen berpengaruh positif dan signifikan terhadap nilai perusahaan dengan level signifikansi $1 \%$. Hasil penelitian ini sejalan dengan penelitianSiallagan dan Machfoedz (2006),Animah dan Ramadhani (2008), Murwaningsari (2008), Kawatu (2009),Febrina (2010),Suhartati dkk. (2011), serta Susanto dan Subekti (2012).Nilai beta dari KA adalah 0,066 dengan nilai t1,785 dan sig 0,043. Dengan demikian dapat disimpulkan bahwa komite audit berpengaruh positif dan signifikan terhadap nilai perusahaan dengan level signifikansi 5\%. Hasil penelitian sejalan dengan Siallagan dan Machfoedz (2006), Murwaningsari (2008), danKawatu (2009).

\section{KESIMPULAN}

1. Corporate social responsibilityberpengaruh positifdan signifikan terhadap nilai perusahaan.

2. Kepemilikan manajerialberpengaruh positif dan tidak signifikan terhadap nilai perusahaan.

3. Kepemilikan institusionalberpengaruh negatif dan tidak signifikan terhadap nilai perusahaan.

4. Dewan komisaris independenberpengaruh positif dan signifikan terhadap nilai perusahaan.

5. Komite auditberpengaruh positif dan signifikan terhadap nilai perusahaan. 


\section{KETERBATASAN}

1. Penelitian ini menggunakan sampel hanya terbatas pada perusahaan yang bergerak di sektor manufaktur. Sehingga hasilnya belum dapat mengeneralisasi seluruh perusahaan non manufaktur di BEI.

2. Penelitian ini menggunakan sampel hanya terbatas pada sampel 2011-2015 sehingga hasilnya belum mengeneralisasi pada tahun penelitian yang lebih luas.

\section{DAFTAR PUSTAKA}

Animah dan Rahmi Sri Ramadhani, 2008, "Pengaruh Struktur Kepemilikan, Mekanisme Corporate Governance, dan Ukuran Perusahaan Terhadap Nilai Perusahaan (Survei pada Perusahaan Manufaktur yang Terdaftar di Bursa Efek Jakarta Periode 2003-2007)”, Skripsi,Universitas Mataram.

Anggraini, Shully, 2012, "Pengaruh Kepemilikan Manajemen, Kepemilikan Institusional, dan Corporate Social ResponsibilityTerhadap Nilai Perusahaan Pada PT Perusahaan Perdagangan Indonesia/ITC (Indonesia Trading Company)", Woorking paper, Universitas Bina Nusantara.

Dahlia, L. dan V. S.Siregar, 2008, “Pengaruh Corporate Social Responsibility terhadap Kinerja Perusahaan (Studi Empiris pada Perusahaan yang Tercatat di Bursa Efek Indonesia pada Tahun 2005 dan 2006)", SNA XI,Pontianak.

Febrina, N., 2010,"Pengaruh Komisaris Independen Dan Kinerja Keuangan Terhadap Nilai Perusahaan (Studi Empiris Pada Perusahaan Wholesale Yang Terdaftar Di Bursa Efek Indonesia)",Skripsi,Universitas Gunadarma.

Kawatu, F. S., 2009, "Mekanisme Corporate Governance Terhadap Nilai Perusahaan dengan Kualitas Laba Sebagai Variabel Intervening”, Jurnal Keuangan dan Perbankan, 13(3):405-417.

Murwaningsari, E., 2008, "Pengaruh Corporate Governance Terhadap Nilai Perusahaan dengan Manajemen Laba Sebagai Variabel Intervening (Studi pada Perusahaan Manufaktur di BEJ)", Vol. 13 No. 2:364-383.

Murwaningsari, E., 2009. "Hubungan Corporate Governance, Corporate Social Responsibilities dan Corporate Financial Performance Dalam SatuContinuum", Jurnal Akuntansi Dan Keuangan, Vol. 11 No. 1:30-41.

Nurlela, R. dan Islahuddin, 2008,"Pengaruh Corporate Social Responsibility Terhadap Nilai Perusahaan Dengan Prosentase Kepemilikan Manajemen Sebagai Variabel Moderating",SNA XI. 
Pujiati, D. dan E. Widanar, 2009, "Pengaruh Struktur Kepemilikan Terhadap Nilai Perusahaan: Keputusan Keuangan Sebagai Variabel Intervening", Jurnal Ekonomi Bisnis \& Akuntansi Ventura, 12(1):71-86.

Permanasari, Wien ika, 2010, "Pengaruh Kepemilikan Manajemen, KepemilikanInstitusional dan Corporate Social Responsibility terhadap NilaiPerusahaan".Skripsi, Universitas Diponegoro.

Purwanto, A., 2009, "Karakteristik Perusahaan, Praktik Corporate Governance, Keputusan Keuangan, Perataan Laba dan Nilai Perusahaan”, Jurnal MAKSI, 9(2):175-189.

Rachmawati, A. dan H. Triatmoko, 2007, "Analisis Faktor-Faktor yang Mempengaruhi Kualitas Laba dan Nilai Perusahaan", SNA X.

Rustiarini, N. W., 2010,"Pengaruh Corporate Governance Pada Hubungan Corporate Social Responsibility Dan Nilai Perusahaan",SNA XIII,Purwokerto.

Saputra, M., 2010,"Pengaruh Corporate Governance Terhadap Nilai Perusahaan Di Bursa Efek Indonesia, Jakarta",Journal of Indonesian Applied Economics,4(1):81-92.

Saputra, S. B., 2010,"Pengaruh Corporate Social Responsibility Terhadap Nilai Perusahaan Dengan Kepemilikan Manajemen Dan Kebijakan Dividen Sebagai Variabel Pemoderasi",Jurnal Akuntansi,Universitas Muhammadiyah Yogyakarta,6(6).

Siallagan, H. dan M. Machfoedz, 2006, "Mekanisme Corporate Governance , Kualitas Laba dan Nilai Perusahaan",SNA IX.

Sofyaningsih, S. dan P. Hardiningsih, 2011, "Struktur Kepemilikan, Kebijakan Dividen, Kebijakan Utang, dan Nilai Perusahaan", Dinamika Keuangan dan Perbankan, 3(1):68-87.

Suhartati, Titi, S. Warsini, dan N. Sixpria, 2011, "Pengaruh Pengungkapan Tanggung Jawab Sosial Dan Praktik Tata Kelola Perusahaan Terhadap Nilai Perusahaan", Jurnal Ekonomi dan Bisnis, vol. 10 no 2, Desember 2011.

Sukirni, Dwi, 2012, “Kepemilikan Manajerial, Kepemilikan Institusional, Kebijakan Deviden dan Kebijakan Hutang Analisis Terhadap Nilai Perusahaan", Jurnal Akuntansi, Fakultas Ekonomi Universitas Negeri Semarang.

Susanti, A. N., Rahmawati dan Y. A. Aryani, 2010, "Analisis Pengaruh Mekanisme Corporate Governance Terhadap Nilai Perusahaan dengan Kualitas Laba Sebagai Variabel Intervening pada Perusahaan Manufaktur yang Terdaftar di Bursa Efek Indonesia Periode 2004-2007”, Simposium Nasional Keuangan I. 
Susanto, Priyatna Bagus dan Imam Subekti, 2012, "Pengaruh Corporate Social Responsibility dan Good Corporate Governance Terhadap Nilai perusahaan (Pada Perusahaan Yang Terdaftar di Bursa Efek Indonesia),Jurnal Ilmiah Mahasiswa, FEB Universitas Brawijaya Vol 1, No 2.

Susilawati, 2009,"Pengaruh Invesment Opportunity Set, Corporate Social Responsibility Terhadap Nilai Perusahaan Dengan Kepemilikan Manajemen, Tipe Industri Sebagai Variabel Moderating",Jurnal Akuntansi,Universitas Muhammadiyah Yogyakarta, 5(5).

Wardoyo dan Theodora M. Veronica, 2013, "Pengaruh Good Corporate Governance, Corporate Social Responsibility \& Kinerja Keuangan Terhadap Nilai Perusahaan" Jurnal Dinamika Manajemen vol. 4, no.2, 2013, pp: 132149 